\title{
Socioenvironmental networks and international cooperation: The Global Alliance for Recycling and Sustainable Development- GARSD
}

\author{
Redes socioambientais e a cooperação internacional: \\ Global Alliance for Recycling and Sustainable \\ Development- GARSD
}

Luciana Aparecida Iotti Ziglio ${ }^{a}$

Wagner Costa Ribeiro ${ }^{b}$

${ }^{a}$ Post-Doc, School of Arts, Sciences and Humanities - EACH/USP, Doctor in Human Geography, University of Sao Paulo, São Paulo, SP, Brazil E-mail: Iziglio@yahoo.com.br

${ }^{b}$ Professor of Human Geography, University of Sao Paulo Researcher of the National Council for Scientific and Technological Development - CNPq São Paulo, SP, Brazil E-mail:wribeiro@usp.br

doi:10.18472/SustDeb.v10n3.2019.19328

Received: 18/11/2018

Accepted: 26/09/2019

ARTICLE- VARIA

\begin{abstract}
Networks of nongovernmental organizations dedicated to socio-environmental issues have emerged in recent decades. The involvement of these networks in the international sphere has enabled new approaches to international cooperation. This article introduces the concept of international cooperation and the Global Alliance for Recycling and Sustainable Development (GARSD), a socio-environmental network created by a coalition of NGOs dedicated to promoting recycling of municipal solid waste. This article is the result of a doctoral study conducted using documentary analysis, participant observation and other qualitative data collection methods. The study conclusively finds that it is necessary to analyze the work of these non-state actors within the context of international cooperation between nation states and the possibility of (re)creating political-territorial arrangements, such as networks comprising a variety of actors especially geared towards socio-environmental issues.
\end{abstract}

Keywords: Non-governmental organizations. International cooperation. National States. Socioenvironmental Networks. GARSD. 


\section{RESUMO}

Durante as últimas décadas, surgiram redes de organizações não governamentais que se dedicam aos temas socioambientais. $O$ envolvimento dessas redes com a esfera internacional ocasiona novas abordagens para a cooperação internacional. Apresentar o conceito de cooperação internacional e a rede socioambiental Global Alliance for Recycling and Sustainable Development - GARSD é o objetivo deste artigo. A GARSD, é resultado da coalização de organizações não governamentais dedicadas à promoção da reciclagem de resíduos sólidos urbanos. O artigo é o resultado de pesquisa realizada em processo de doutoramento, que utilizou por procedimentos metodológicos a análise documental, pesquisa participante e a coleta de dados de abordagem qualitativa. Conclusivamente, torna-se inerente analisar as atuações destes atores não estatais diante das relações de cooperação internacional estabelecidas entre Estados Nacionais na possibilidade para a (re)criação de arranjos político-territoriais como a construção de redes entre os diversos atores, especialmente, nos temas socioambientais.

Palavras-chave: Organizações não governamentais. Cooperação internacional. Estados Nacionais. Redes Socioambientais. GARSD.

\section{INTRODUCTION}

Nation states, holders of legal capacity in the ambit of Public International Law, have articulated, in the last decades, proposals to seek a sustainable environment. The objective is to provide a healthy environment to societies, which involves issues associated to quality and quantity water availability, air pollution and management of solid urban wastes, among other aspects.

With consumption increase, urban solid waste management becomes a challenge. Data from the World Bank (KAZA, et.al, 2018, p.17) indicate that its production worldwide, in 2016, reached around 2.1 billion tons. For 2050, the institution estimates 3.4 billion tons. In face of this scenario, it is necessary to advance research and international meetings to encourage non generation and appropriate management of wastes.

International environmental conferences, like Rio 92 (1992) and Rio +20 (2012) gathered heads of state, , representative of university research centers, environmentalists, press, non-governmental organizations (NGOs) and members of the civil society to debate themes like environment conservation, climate changes, desertification, and solid wastes, among others. Such meetings gathered participants in official sessions and, simultaneously, in parallel forums, particularly for socio-environmental movements and civil society representatives.

Since 1992, spheres of the society gathered and took a position in face of socio-environmental themes by means of non-state actors from several countries. Little by little, "NGOs and their international relations were an important element to align the world society and, particularly, the Brazilian society, with the new complexities and their paradigms" (OLIVEIRA, et al., 2007, p.1).

The increasingly more distinguished role of NGOs, especially those working with socio-environmental themes, is one of the justifications for this paper. By means of international cooperation, they influence the states to create and ratify international treaties on socio-environmental issues, seeking to implement the Public International Law. However, as warns Diegues (2008), even by contributing to deepen international cooperation relations with their socio-environmental actions in different localities, monitoring and inspection of interventions practiced by these non-state actors should occur, since, in many cases, they act where the state is not present.

Discussing international cooperation associated to the networks of non-state actors for socioenvironmental theme requires re-thinking States' agendas and establishing new reading for the relations between state and society. Moreover, the proliferation of NGOs networks indicates not only a quantitative vector, but also requires quality assessment of the scope of actions of these organizations. 
It is not about assessing their performance like isolated agents, but their capillarity and insertion in the society, particularly with regard to themes that the state did not face with the required urgency.

This paper aims at addressing a specific network, the Global Alliance for Recycling and Sustainable Development (GARSD), which emerged from the international cooperation for management of urban solid wastes. With its socio-environmental actions, the network seeks to expand its speech and, simultaneously, position itself as an important non-state actor in the international cooperation with States.

Turned to the management of urban solid wastes by means of practices that encourage recycling, the GARSD seeks to face one of the most serious contemporary problems: increase in waste generation indices. Data from the World Bank (Kaza, et.al, 2018, p. 3) demonstrate increase in world production between $19 \%$ and $40 \%$ for the coming years. This increment is directly associated to per capita income values of countries. The network works in countries that, according to World Bank projections (Kaza, et.al, 2018, p. 3), can present raise of up to $40 \%$ in solid waste generation until 2050. Brazil, Argentina, Mexico and South Africa can have $15 \%$ to $20 \%$ increase, while for Thailand and increase of around $30 \%$ is estimated for 2050.

Data from this same institution indicate that world recycling and composting indices reach $19 \%$ of the total generated, and the final disposal in open dumps reaches $33 \%$ of the total of urban solid wastes. The countries involved by GARSD NGOs present recycling indices below $15 \%$ of the total of wastes produced. On the other hand the final destination in open dumps presents numbers far above the world average (KAZA, et.al, 2018, p. 5).

It is also worth mentioning that such final destination of solid wastes in open dumps causes the movement of individuals to these locations, creating the waste mining. That because, for these populations, it is the way of making money even under socio-environmental vulnerability (DIAS, 2012; ROGGERO, 2018;). Data from the World Bank state that large Latin-American cities have, on average, 4 thousand waste pickers (KAZA, et.al, 2018, p. 55). The GARSD involves eight countries, of which six are from Latin American.

The central objective of the text is to point out how the creation of GARSD proved to be an alternative to solid waste management for some metropoles. For that, the paper presents the following structure: introduction, methodological procedures, theoretical contributions on international cooperation and non-governmental organization, history of GARSD network, along with contemporary analyses of the theme and, finally, the final considerations.

\section{METHODOLOGICAL PROCEDURES}

This paper results of a doctorate research with monographic, contemporary, phenomenological and participative approach.

Monographic is understood, according to Eco $(1985$, p.10) as "the approach to one single theme, addressing its description and behavior" (translated). This idea is complemented by Severino (1996, p.150), who defines monograph as the "approach to a single theme that requires own research in the scientific field where it is situated, like specific methodological instruments" (translated). Therefore, it is seen as monographic for presenting the emergence of socio-environmental networks, specifically the GARSD.

A theme is considered contemporary when it is under permanent construction, such as occurs with the network of NGOs analyzed in this article. As states Eco $(1985$, p.13), "the contemporary theme is always more difficult. (...) there is, usually, a more reduced bibliography (...)" (translated). It is understood as contemporary for discussing a highly relevant theme: management of urban solid wastes. Moreover, it analyzes the first manifestations of the network, its emergence and initial challenges as socioenvironmental network. 
According to Diehl and Tatim (2004, p. 50), a research is conceptualized as phenomenological when it "concerns with the direct description of the experience as it is" (translated). This research procedure was used for the network presentation.

Participatory research was also adopted for the research. It is described by Brandão (1988, p.34) as "learning to improve the research through action, through participatory research". The author's involvement with the network made possible the direct observation of information and reports that resulted in materials disposed on electronic and print media of GARSD network. She also participated in meetings organized by the network as technical advisor.

In order to provide support to the participatory research, the qualitative approach was used. This approach is conceptualized according to Tatim et al. (2004, p.52):

- data are collected preferably in the contexts on what the phenomena;

- data analysis is developed, preferably, while they are being collected;

- studies are presented in a descriptive way, with focus on the understanding and interpretation in the light of the meanings of the subjects themselves and other associated references in the literature;

- the theory is built by means of analysis of empirical data, to be later improved with the reading of other authors;

- interaction between researcher and researched is fundamental, reason why it is demanded from the researcher improvement in techniques associated to the object.

Finally, document analyses were included by means of review of literature found in books and articles by reference researchers in the universe of human sciences, particularly Geography, International Relations, and Social Sciences, to analyze definitions of NGOs, networks and international cooperation.

\section{INTERNATIONAL COOPERATION AND NON-GOVERNMENTAL ORGANIZATIONS}

In the last decades, there has been increase in international treaties and the creation of programs to encourage cooperation in its multiple forms: economic, environmental, technical and scientific. Many of these relations, according to Gosovic (2016) occur between countries from the North and South hemispheres. Hence, to understand this current scenario of relations, one must review the notion of international cooperation; learn who are the actors involved, and the means and objectives chosen by them.

The initial premise is that countries are the main actors in international relations to solve world impasses. However, this scenario has recently received the inclusion of other international actors like NGOs. For authors of the political realism geopolitical tradition, cooperation is intended to ensure the order of the system of Nation States founded on the principles of sovereignty, since the non-existence of authority above states makes each of them responsible for their own survival. Therefore, as described by Aron (2002, p.54) "States issue rules destined to ensure their aspirations" (translated). International relations and cooperation are used to maintain states sovereignty.

In the theoretical matrix of political realism, Nation States are the actors that channel, block and control economic, social and environmental actions in the international scenario. Thus, there is no need to cooperate with non-state actors, which are not included in inter-state relations. It is remarkable, according to Villa (1999, p.22), that "state actors in the international plan use violent (coercion) and non-violent (consensus) means to be successful with the desires expressed by their will" (translated). In other words, expressed by Villa (1999, p.23), "they use good weapons and good laws" (translated). Under the realism perspective, a NGO translates the expression of state control in actions on the territory only where it has legal legitimacy, defined by the State. In this conception, international 
cooperation is a task of the State and NGOs would play a secondary role, restricted to the interior of the national territory as long as in accordance with the interests defined by the sovereign power.

International relations' theories define international cooperation as a principle that walks in the opposite direction of conflict. As pointed out by Outhwaite (1996, p.119), "we can say that two or more agents cooperate when they commit to a joint undertaking for whose result actions by both are required" (translated).

For cooperation to occur, there must be common objectives among the Nation States in certain moments, however, other interests can interfere with the cooperation process. Thus, Bobbio (1995, p.287) "States cooperate so that this association will represent their interests and activities through the solidarity to collaboration forms, because from it the removal or neutralization of conflict elements can occur" (translated). However, States are also concerned with ensuring their sovereignty when they assume international commitments to avoid intervention in domestic affairs.

The interdependence theory examines, in addition to cooperation, the transnationalism phenomenon, that is, the emergence of new non-state actors beyond state frontiers. For Nye e Keohane (2001), interdependence of actors in the international system would increase cooperation. However, this interdependence is not symmetrical, but complex. It establishes power differences among actors and is present in cooperation agreements, and, to occur, it may even cause tensions before its concretization. Therefore, as stated by Keohane et.al:

[...] Interdependence, most simply defined, means mutual dependence. Interdependence in world politics refers to situations characterized by reciprocal effects among countries or among actors in different countries. (...)The effects of on interdependence will depend on the constraints, or costs, associated with them (KEOHANE, et.al, 2001, p.7-8).

Keohane et. al (2001) also present fundamental aspects of complex interdependence:

Multiple channels connect societies, including: informal ties between governmental elites as well as formal foreign office arrangements; informal ties among nongovernmental elites (face-toface and through telecommunications); and transnational organizations (such as multinacional banks or corporations). These channels can be summarized as interstate, transgovernmental, and transnational relations (KEOHANE, et.al, 2001, p.21).

The emergence of new non-state actors like NGOs poses new questions for international cooperation and the classical realistic paradigm. Cooperation among non-state actors in different countries points to transnational cooperation and its relation with Nation States. A transnational relation is the one that transcends States' frontiers, involving several actors, including non-state actors, like NGOs. As stated by Villa $(2001$, p. 83) "thus is considered, then, the concrete practice of transnational relations and their interactions with inter-state and supranational levels" (translated).

International cooperation, therefore, is different from the realistic view - like an open, decentralized, non-linear process that can have a transformation impact on actors and on the functioning of the international system, but still with prevalence of Nation States in these sharing relations (Sikkink, 2005).

Therefore, cooperation definition goes beyond the traditional conception of the political realism theory. In addition to the aspects already mentioned, it suffers influence of domestic and international factors, and can cause transformations in actors and in the international system, affecting the prevalence of Nation States, since the actors involved are not only countries. Based on this conception, international cooperation should also be analyzed in arenas of discussions of non-state actors, as occurs with GARSD. In this context, cooperating means for NGOs a new understanding of reality and political processes, on what there is no longer room for a unified historical subject, but for multiple actors that express 
diversity of identities and pluralism that enriches the approach to environmental issues (Bulkeley, 2005; CONCA et.al, 2002).

From this perspective, international cooperation makes possible the insertion of new non-state actors, like NGOs, in the dynamics of relations with States. It is understood, therefore, that international socioenvironmental NGOs are forms of social organization, constituted of political subjects that reinvent the political action to beyond State and society relations.

NGOs 'political actions' can contribute to cooperate with and/or contest, in national or international dimension, social rights. International socio-environmental NGOs, as characterized by Herculano (2000, p.1) "are legal forms institutionalized by States, maintained by the private or public sector, or both, with participation of the society, which are organized around the so called social rights" (translated).

Social right can be, for example, to seek a healthy environment for populations living in a given area of a country's territory. This social right is also a socio-environmental right, understood as the one that allows the being to reproduce himself in a dignified manner as individual and member of the collective, who expresses values and respect socially determined practices in a place with natural attributes or attributes produced by work. That is, under the terms of the international environmental system, international cooperation is fundamental (Ribeiro, 2001). This set of international treaties is under construction and will only gain relevance with concrete actions, many of which end up by being implemented by NGOs, whether operating in network or not.

Here it is defended that the concept of international cooperation should advance to contemplate the number of actors and consider a NGOs, to expand the analysis of the international system, the dynamics the networks created by them provide, especially for socio-environmental issues.

\section{NON-GOVERNMENTAL ORGANIZATIONS AND SOCIO-ENVIRONMENTAL NETWORKS}

The English expression "Non-Governmental Organizations" (NGOs) was used for the first time in the United Nations in 1950 to refer to organizations operating at supra- and international level and that were not established by government agreements. These organizations were not seen as relevant actors for international cooperation studies. Davies (2014, p.885) says "It is partly on account of this mid-20th-century change of terminology that writings on NGOs since this date have largely neglected the earlier literature on "private international organizations'" working long before the creation of the United Nations, years before the First World War (1914-1918).

However, at the United Nations Conference on Environment and Development (UNCED), also known as Rio 92 for being held in Rio de Janeiro in 1992, the simultaneity of meetings of heads of State with the NGOs Forum resulted in higher visibility to non-state actors' agenda, another classical definition assigned to NGOs. At that Conference, for the first time in UN meetings, NGOs could integrate the official delegation of countries (RIBEIRO, 2001). Thus NGO definition' assumed a new dimension. According to preparatory document of the NGOs and social movements' forum for the environment and development:

NGOs are public spaces outside the sphere of the State, responsible for instituting new values, norms and standards of behavior that deeply question the current model of development and for this reason are, today, the actors potentially most capable of romper with the individualistic and predatory logic (BRASIL, 1992, s.p.).

According to Castells (1999), the complexity of relations in the current model of development is a consequence of the advance of globalization, which generated the development of networks to 
disseminate information, culture, production processes, among other aspects. Many networks may involve NGOs or be formed exclusively by them, as is the case of GARSD.

Therefore, NGOs, now supported by the private sector, now by the State, or by both, build networks around the world, fighting for their aspirations. These actors express themselves with different socioenvironmental objectives, from local economic development to actions associated to social rights and environmental protection. Such diversity many times pulverizes efforts that can be catalyzed in a network, which, in addition to providing more visibility to their demands and social struggles, can also gather efforts and resources to optimize outcomes.

NGO networks dedicated to environmental themes defend as alternative to the predatory logic of use of natural resources, the conservation or restoration of the environment damaged and the application of the eco-efficiency theory1, among other possibilities. In this proposal "is not committed to a unique type of value expressed in a single numeraire [...] encompasses money valuation, [...] physical appraisals of the contribution from Nature and the environmental impacts of the human economy [...]" (MARTINEZ-ALIER, 2007, p. 26). This NGO profile seeks environmental preservation with social participation by means of technological instruments and with the dissemination of environmental education information, for example.

On the other hand, NGO networks turned to economic and social development actions also create projects for income generation and reduction in indices to population excluded from the job market. So, programs emerge that attract, for example, youth seeking the first job, elderly, women and disabled persons. That because corporate economic relations do not choose them as their first candidates and, as explained by Tamiko, unemployment selects these publics, preferably, since:

[...] alongside the problem of youth unemployment, we can't neglect the difficulty to include middle-aged and elderly persons in the job market [...]. As to the "experimental" job, companies avoid elderly applicants, fearing the obligatoriness of granting them a regular position (TAMIKO, 2009, p.239) (translated).

Thus, NGOs, particularly after the 1990s, presented in national and international scale, and by means of their networks, projects intended to collaborate to economic development. Such insertions created stronger relations with public and private spheres dedicated to the theme. The environmental issue also followed this model. NGOs articulated in networks can control and tame excluded public spaces and populations. As described by Raffestin while analyzing territory:

To domesticate is, therefore, to enclose in a network, a mesh, where all parts are under the look (...) Networks do and undo the prisons of the space made into territory: they both set free and imprison, because they would be an instrument to obtain power (RAFFESTIN, 1993, p.39; 204) (translated).

Haesbaert (2004, p.280), on the other hand, defines the experience in networks by stating that "territorializing today also means building and/or controlling flows and networks and creating symbolic references in a space in motion". With this premise, a NGOs network undertakes a territoriality that, where it doesn't compete with the State, transcends its territory for the permeability it reaches, particularly when it spreads across several countries, as the case of GARSD.

Therefore, by observing the movements of these networks we can review the dynamics of international cooperation and the articulation of powers among actors that it causes, particularly between NGOs and States, and also and mainly, their "political action", revealed as (re)creation of political-territorial arrangements. 


\section{THE INTERNATIONAL SOCIO-ENVIRONMENTAL NETWORK GLOBAL ALLIANCE FOR RECYCLING AND SUSTAINABLE DEVELOPMENT: GARSD}

GARSD is an international socio-environmental network created in 2007, which results from the cooperation of NGOs from different countries. Its initial core involved the following countries and NGOs: Brazil - Compromisso Empresarial para Reciclagem (CEMPRE), Thailand - Thailand Institute of Packaging Management for Sustainable Environment (TIMPSE), Uruguay - Compromiso Empresarial para el Reciclaje (CEMPRE - Uruguay) and Mexico - Compromiso Empresarial para el Manejo Integral de Resíduos A.C. (SUSTENTA).

The network main objective is the incentive to recycling of urban solid wastes. In order to concretize it, its goal is to encourage practices that will promote: reduction in final disposition of recyclable materials in open dumps and landfills; increase in recycling rates at international level through national projects by NGOs that integrate the GARSD; increase in the number of workers involved in recyclable materials, from collection to industrial transformation. It is also fundamental to achieve its objective the establishment and creation of non-governmental organizations in several countries, thus creating a more comprehensive network.

The founding organizations with their respective representatives gathered for the first time in São Paulo, in 2007, to establish proposals for the following prerogatives: it is known that household urban solid wastes assume dimensions of local-global scale, and so, what are the instruments for their effective management? Which actors are involved in the management of urban solid wastes? What is the role of NGOs in the field of management?

GARSD, to present answers to the questions raised and guarantee its existence started the network work and its components made efforts to create electronic publications, educational campaigns and a page on the electronic network to transmit their values on electronic media.

In order to extend its speech, GARSD edits publications, among which the following are outstanding: Guidelines for establishing solid waste recovery organizations in emerging countries and Guidelines to set waste pickers cooperatives ${ }^{2}$.

The first, in electronic version, presents the steps to establish a non-governmental organization in a country that does not integrate the network. The premises to form a non-governmental organization turned to the qualification to manage solid wastes consider: finding companies interested in encouraging recycling by means of practices executed by NGOs; hiring of technical teams to promote projects; data banks on recycling and solid wastes; disposition to form technical teams to establish and analyze the creation of networks with multiple actors, with emphasis to States' spheres.

Moreover, this publication contains information on the members of GARSD network, their localization, and foundation date, main activities locally performed, like data banks of recycling companies or a brief presentation of applied environmental education projects.

The second publication, Guidelines to set waste picker cooperatives is available in print format, in English and Spanish. The objective is to make of it a tool for consolidation, in world scale, of the model of recyclable material waste pickers' cooperatives in the management of domestic urban solid wastes. Such material, available to experts in management of domestic urban solid wastes contains technical and legal instructions to create waste pickers' cooperatives.

In the technical aspect, models of equipment for collection, sorting and recycling of materials are found; in the legal field, guidance on tax, fiscal and environmental mechanisms, and how they are subject to national laws. According to GARSD network, this publication is intended to assist in the organization of "association of waste pickers in order to strengthen them to buy and sell recyclable materials at better prices [...]" (Garsd, 2011, p.4). The network doesn't count yet with a methodology to follow-up the application of practices provided in this publication. 
Finally, the page on the world wide web ${ }^{3}$ gathers the main GARSD information, as well as the contact of each participating NGO, which makes possible exchange of information with those interested in the management of household urban solid wastes. The electronic page is used as a contact portal with those interested in solid waste management from the perspective advocated by GARSD, and aims at expanding the dissemination of its practices, which would increase its influence in this sector.

With regard to the meetings organized by GARSD, after the event from which the network originated, three other meetings are outstanding: Thailand (2009), Brazil (2011), and Washington (2013). In general, the activities proposed in these forums sought to establish guidelines and exchange of experiences in the implementation of their projects in the countries where GARSD is inserted.

In the 2011 event, held in Brazil, the central discussion addressed the following pillars: continuation of projects related to the promotion of environmental education to encourage selective collection; practices of incentive to organization of groups of recyclable material waste pickers in all member countries; actions to harmonize new proposals of creation of projects on the network to be applied to the community, government - in its different levels - and the private sector. It is worth reminding that these themes had been already defined by the network in 2009, in a meeting in Bangkok, Thailand.

The formalization of entry of new NGOs to GARSD network was concretized in these meetings. In 2011, Compromiso Empresarial para Reciclaje CEMPRE COLOMBIA, located in Colombia, Pet Plastic Recycling South Africa (PET CO), located in South Africa and RECICLAME, located in Peru were included. PETCO entry in GARSD permits to present to the African continent its aspirations and projects. The entry of CEMPRE COLOMBIA and RECICLAME, on the other hand, reinforce the presence in Latin America.

The 4th GARSD meeting, held in Washington in 2013, along with the Inter-American Development Bank (IBD), focused on analyzing the current situation of solid waste management in Latin America and Caribbean countries and debated the network experiences in order to expand them and/or adapt them to other member countries. In this forum, public policies for management of solid wastes in Brazil, like the National Policy for Solid Wastes approved in 2010, deserve highlight for being the first law approved among countries of the network that included waste pickers of recyclable materials in the thematic in twelve of its fifty seven articles (Brasil, 2010). Moreover, the network presented proposals of projects to IDB aiming at "release of resources for actions of urban solid waste management promoted by GARSD" (Cempre Informa, 2013, s.p, translated). In 2018, the network counts on 8 members, as shown in map I. The most recent entry was Cempre Argentina, in 2017.

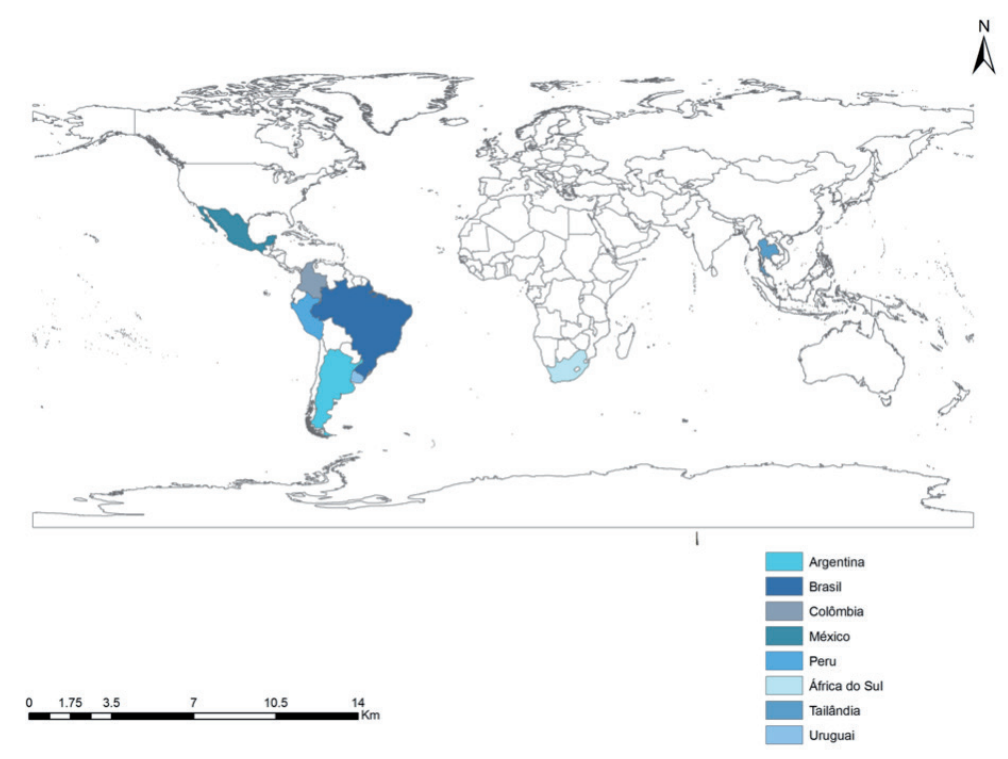

Map 1 | Global Alliance for Recycling and Sustainable Development - GARSD - Member Countries Source: Miranda, 2018. 


\subsection{GARSD: CONTEMPORARY ANALYSES}

Constituted by NOGs consolidated in their countries of origin, GARSD, as non-state actor, starts the construction of cooperation, as states Sikkink (2005), with an open, decentralized, non linear and repetitive process in order to reach cooperative relations with States and legitimate its position and speech in the international scenario. The open and decentralized cooperation movement emerges with the search for companies interested in creating and financially maintaining a non-governmental organization in a country that is not member of GARSD network. In a linear movement of cooperation, institutions would seek the cooperative act directly with the State. Therefore, the network initial procedure is the non linear cooperation, with private players. The repetition mechanism of search for private organizations interested in founding non-governmental organizations in several countries influences all members of the network.

Thus, GARSD, with its practices, intends to establish an inter-dependent and complex international cooperation (Keohane, et.al., 2001) with States regarding solid waste management. For such, it uses open, decentralized, non linear and repetitive processes.

The driving principle for GARSD is cooperation and when this principle is established with a NGO from a new Nation State where it didn't operate until then, it reaches its first objective. The network intends to become a non-governmental player with global dimension and become reference in solid waste management in order to increase recycling rates in member countries. Only the cooperation with the State will allow aspirations to be materialized in public policies by the network countries. Thus, the network attempts to be available for cooperation among States because it believes that, while presenting techniques of solid waste management it assumes, as states Outhwaite (1996), a joint undertaking with the public sphere, whose outcome will be the cooperation between both, necessary for the consolidation of an agenda of waste management. In case the States accept the network proposals, the cooperation has become convergent.

GARSD, as conceptualized by Bulkeley (2005), with its cooperative practices, reveals multiple players for socio-environmental issues and another understanding of reality and political processes in generation and management of urban solid wastes.

By means of its transnational practices (such as: organization of electronic publications and references intended to increase recycling rates, establishment of meetings with the network members or with other international organisms - like IDB) it seeks to be strengthened as non-state actor in the international system. For its members, the network consolidation as international player is strengthened by transnationalism (VILLA, 2001).

During Rio 92, NGOs found a prosperous scenario and they were introduced along with official players to discuss global environmental agendas. In this favorable context emerged CEMPRE BRASIL, conceived in NGOs Forum in Rio 92, after the meeting with environmental experts that participated in the event. It was the starting point, after twenty years, for the emergence of other NGOs across the world and in network, with GARSD name. After 20 years, at Rio + 20, GARSD network was present in the Social Forum presenting its actions and its members' evolution. That is, with regard to urban solid wastes and their management with social inclusion, CEMPRE Brasil became a centralizing reference that resulted in GARSD.

The GARSD seeks to participate in large world events of the international environmental order. Similar organizations, like Greenpeace, World Wildlife Fund (WWF) and Nature Conservancy (TNC) as contextualized by Diegues (2008) and Marzochi (2013) became expressive players in international environmental events. GARSD clearly expresses this goal of becoming reference in urban solid waste management with social inclusion.

As states Castells (1999) technological networks for dissemination of information, culture, processes and other appropriate interests are present in the world today. Therefore, emerges the "society in 
network that originated by the end of the 60s and mid 70s [...] where actors like environmentalists would be elements of this age" (Castells,1999, p. 412). So, the correlation to be made in this direction is that the creation of electronic publications and page reaffirms that environmentalists use technological networks to increase the number of individuals to follow and legitimate their convictions. More than that, they articulate in periodical meetings where they establish forms of action by means of exchange of experiences and applied techniques that were successful, in GARSD case, involving recycled material waste pickers based on the experience developed in Brazil, supported by the National Policy for Solid Wastes (Brasil, 2010). Later, other experiences were included, like, for example, those by TIMPSE (Thailand) and RECICLAME (Peru).

GARSD's political action, that is, speeches expressed in publications and through its components, are legitimated by means of different insertions, such as: forums, advertising campaigns, publications, selective collection projects with civil society and encouragement of recycling by organizing waste pickers' cooperatives with job opportunities for population groups. Among them, programs like the first job and other programs turned to elderly, women and disabled persons can be mentioned, as characterized by Tamiko (2009). However, such 'political action' is validated when these socio-environmental NGOs are transformed, as described by Herculano (2000), into legal forms institutionalized by the State in favor of social rights.

On the other hand, it is necessary to acknowledge that non-governmental organizations, for being maintained by the "financing of their projects sometimes by the public sector, other times by the private sector or by both" (Herculano, 2000, p.1, translated) end up by keeping relations with neoliberal policies and projects. That would be, in Hardt e Negri (2001, p. 332) words "the community face of neoliberalism". Thus, these actors are multifaceted. While presenting themselves as "nongovernmental", they are positioned, many times, alongside private interests. GARSD is kept as nongovernmental organization with resources financed by the private sector and some of its members established this type of relations with public institutions.

As already explained, it is understood that networks are geopolitical formations with hierarchies defined and/or flexible according to the interests of their players in order to share power. Networks, as described by Raffestin (1993, p.39; 204) are "instruments for obtention of territorial powers". The network established among GARSD members aims at being an instrument to obtain territorial insertions and powers in public policies' agendas turned to the management of solid wastes in the countries where they operate.

GARSD, like other NGO networks, is not positioned in face of more polemic socio-environmental issues. As states Haesbaert (2004, p.280) they seek to "ensure with their actions the construction and/or control of flows and networks creating symbolic references in spaces and so, territorializing" (translated). However, we should emphasize the importance of analyzing the themes that these groups address, and at the same time verify their financiers and other peers within international cooperation, which can, jointly, multiply their speeches. GARSD establishes rules according to what it defends, a task that results from external financing whose main source is the private sector.

\section{FINAL CONSIDERATIONS}

International cooperation is the outcome of a convergence of interests, even being asymmetrical interests. Where it involves local actors based on general guidelines, an influence network can be established that transcends the initial objective of local and national actors.

While presenting itself as articulator of NGOs that operate with management of urban solid wastes in countries across the world, GARSD network ends up by establishing a new reference in waste management. It was associated to social inclusion by incorporating workers who collect and separate the material. 
But the network seeks to increase its influence. The speech produced by GARSD is turned to the intervention in the management of solid wastes internationally. Its members seek to execute roles in the public sphere of the network countries. Due to that, they seek to influence public policies turned to the establishment of their intentions in territories.

The civil society, while relating to NGOs, poses to these subjects the urgency of the solution to their socio-environmental demands. However, the organizations' actions do not necessarily have this purpose. This mismatch can render difficult the implementation of important proposals and show that, after all, it is a rhetorical exercise, without tangible advances, many times due to several types of restrictions, from financiers, or from the State. Nevertheless, the engagement of recycled material waste pickers increased, which led to more social insertion of this population segment.

\section{NOTES}

1. The debate on eco-efficiency involves precepts like ecological modernization, green capitalism and ecology of results. This set of possibilities is vey criticized by approaches involving political ecology, environmental justice and critic socio-environmental theories, among others. To deepen this debate, see, among others, Gorz and Bosquet (1978), Jacobi (2003), Lipietz (2003), Martinez Alier (2007), Burns and Lemoyne (2007), Acselrad, Mello and Bezerra (2009), Moreno Jiménez (2010), Veiga (2010), Ribeiro (2010), Abramovay (2012), Cavalcanti (2012), Naoufal (2016) and Swyngedouw (2019).

2. Available on: < https://pt.scribd.com/document/63260754/Guidelines-for-Establishing-Solid-Waste-RecoveryOrganization-Guidelines-in-Emerging-COuntries-DRAFT-2-12-10 >. Access on Sept 052019.

3. See the network electronic page at the address: www.garsd.org. Access on Sept 052019.

\section{REFERENCES}

ABRAMOVAY, Ricardo. Muito além da economia verde. São Paulo: Editora Abril, 2012.

ACSELRAD, Henri., MELLO, Cecilia e BEZERRA, Gustavo. O que é justiça ambiental. Rio de Janeiro: Garamond, 2009.

ARON, Raymond. Paz e guerra entre as nações. Brasília:IPRI/FUNAG, 2002.

BOBBIO, Norberto. et. al. Dicionário de Política. Brasília: UNB, 1995.

BRANDÃO, Carlos Rodrigues. Pesquisa Participante. São Paulo: Brasiliense, 1988.

BRANISLAV, Gosovic. The resurgence of South-South cooperation, Third World Quarterly, 37:4, 733-743, 2016. Available on: DOI: <10.1080/01436597.2015.1127155>. Access on: Sept 052019.

BRASIL, RIO 92. Meio Ambiente e Desenvolvimento - Uma Visão das ONGs e dos Movimentos Sociais Brasileiros. Fórum de ONGs Brasileiras preparatório para a Conferência da Sociedade Civil sobre Meio Ambiente e Desenvolvimento. Rio de Janeiro, 1992.

BRASIL. (2010). Presidência da República. Lei número 12.305, de 2 de agosto de 2010. Institui a Política Nacional de Resíduos Sólidos; altera a Lei no 9.605, de 12 de fevereiro de 1998; e dá outras providências. Disponível em: < http://www.planalto.gov.br/ccivil_-03/_Ato2007-2010/2010/Lei/L12305.htm >. Acesso em: 05 de set.de 2019.

BULKELEY, Harriet. Reconfiguring environmental governance: towards a politics of scales and networks. Political Geography,v. 24,p. 875-902,2005. 
BURNS, Thomas J.; LEMOYNE, Terri. Como os movimentos ambientalistas podem ser mais eficazes: priorizando temas ambientais no discurso político. Ambient. soc., Campinas, v.10, n.2, p.61-82,Dec. 2007.Disponível em: <http://www.scielo.br/scielo.php?script=sci_arttext\&pid=S1414-753X2007000200005\&lng=en\&nrm=iso>. Acesso em: 05 de set. de 2019. http://dx.doi.org/10.1590/\$1414-753X2007000200005

CASTELLS, Manuel. A sociedade em rede. A era da informação: economia, sociedade e cultura. São Paulo: Paz e Terra, 1999, vol.1.

CEMPRE e Banco Interamericano de Desenvolvimento (BID) realizam evento para promoção do modelo brasileiro de reciclagem. Cempre Informa, 16.out. 2013. Disponível em: <http://cempre.org.br/artigo-publicacao/imprensa/ id/1/cempre-e-banco-interamericano-de-desenvolvimento--bid--realizam-evento-para-prom > . Acesso em: 05 de set.de 2019.

CAVALCANTI, Clóvis. Sustentabilidade: mantra ou escolha moral? uma abordagem ecológico-econômica. Estudos avançados, 2012, vol.26, n.74, pp. 35-50 Disponível em:<http://dx.doi.org/10.1590/S0103-40142012000100004>. Acesso em: 05 de set.de2019.

CONCA, Ken., DABELKO, Geoffrey. The problems and possibilities of environmental peacemaking, in: Environmental peacemaking, edited by: Conca, K. and Dabelko, G., John Hopkins University Press, Baltimoore, 220-233, 2002.

DAVIES, Thomas. Richard. Understanding non-governmental organizations in world politics: The promise and pitfalls of the early 'science of internationalism.' European Journal of International Relations, 23(4), 884 905, 2017. Available on: <https://doi.org/10.1177/1354066116679243>. Access on: Sept 042019.

Diegues, Antonio. A ecologia política das grandes ONGs transnacionais conservacionistas. São Paulo: NUPAB. Universidade de São Paulo, 2008.

GLOBAL ALLIANCE FOR RECYCLING AND SUSTAINABLE DEVELOPMENT. Guidelines for Establishing Solid Waste Recovery Organizations in Emerging Countries.. Disponível em: < https://pt.scribd.com/document/63260754/ Guidelines-for-Establishing-Solid-Waste-Recovery-Organization-Guidelines-in-Emerging-COuntriesDRAFT-2-12-10 > . Acesso em : 05 de set. De 2019.

GLOBAL ALLIANCE FOR RECYCLING AND SUSTAINABLE DEVELOPMENT. GARSD. Guidelines to set waste picker cooperatives. São Paulo: Neuronia Design, 2011.

GONÇALVES-DIAS, Sylmara. Lopes.Francelino.; SANTOS, Maria. Cecília. Loschiavo . A inserção dos catadores no Campo da Indústria de Reciclagem: uma análise comparada de duas experiências de Redes de Economia Solidária. In: Sonia Maria Flores Gianesella; Pedro Roberto Jacobi. (Org.). A sustentabilidade socioambiental: diversidade e cooperação. 1ed.São Paulo: Annablume Editora, 2012, v. 1, p. 98-120.

GORZ, André., BOSQUET, Michel. Ecologie et politique. Paris : Seuil, 1978.

HARDT, Michael., NEGRI, Antonio. Império. Rio de Janeiro: Record, 2001.

HAESBAERT, Rogério. O mito da desterritorialização: fim dos territórios a multiterritorialidade. Rio de Janeiro: Bertrand Brasil, 2004.

HERCULANO, Selene. ONGs e movimentos sociais: a questão de novos sujeitos políticos para a sustentabilidade. Revista Meio Ambiente: questões conceituais, p.123-155,2000.

JACOBI, Pedro Roberto. Movimento ambientalista no Brasil. In: Wagner Costa Ribeiro. (Org.). Patrimônio Ambiental Brasileiro. São Paulo: Edusp, 2003, p. 519-543. 
KAZA, S. et al. What a Waste 2.0: A Global Snapshot of Solid Waste Management to 2050 Urban Development Series. International Bank for reconstruction and development. The world bank. 2018. Available on < https:// openknowledge.worldbank.org/handle/10986/2174 >. Access on: March 272019.

KEOHANE, Robert. O., NYE, Joseph. Power and Interdependence.New York: Longman:, 2001.

LIPIETZ, Alain. Ecologie politique. Paris : La Decouverte, 2003.

MARTINEZ ALIER, Joan. The environmentalism of the poor: a study of ecological conflicts and valuation. Massachusetts: Edward Elgar Publishing, 2002.

MARZOCHI, Samira. GREENPEACE: mundalização e política. Rio de Janeiro: Beco do Azougue, 2013.

MORENO JIMÉNEZ, Antonio. Justicia ambiental. Del concepto a la aplicación en análisis de políticas y planificación territoriales. Scripta Nova. Revista Electrónica de Geografía y Ciencias Sociales. [En línea]. Barcelona: Universidad de Barcelona, 1 de marzo de 2010, vol. XIV, no 316. Disponível em: <http://www.ub.es/geocrit/sn/sn-316.html>. Acesso em: 05 de set.de 2019.

NAOUFAL, Nayla. (2016). Connexions entre la justice environnementale, l'écologisme populaire et l'écocitoyenneté. [VertigO] La revue électronique en sciences de l'environnement, 2016, vol. 16, nำ. Disponível em: < https:// www.erudit.org/fr/revues/vertigo/2016-v16-n1-vertigo02678/1037574ar/> Acesso em: 05. de set. de 2019.

OLIVEIRA, Rafael Santos de; WEBER, Catiane Trevisan. Atuação das organizações não-governamentais ambientalistas: uma perspectiva internacional. Âmbito Jurídico, Rio Grande, X, n. 40, abr. 2007. 09. out. 2018. Disponível em: <http://www.ambitojuridico.com.br/site/index.php?n_link=revista_artigos_leitura\&artigo_ id=1733\&revista_caderno=5>. Acesso em:05 de set.de 22019

OUTHWAITE, William., BOTTOMORE, Tom. Dicionário do pensamento social do Século XX. Rio de Janeiro: Jorge Zahar, 1996.

RAfFESTIN, Claude. Por uma Geografia do Poder. São Paulo : Ática, 1993.

RIBEIRO, Wagner Costa. A ordem ambiental internacional. São Paulo: Contexto, 2001.

Teorias socioambientais: em busca de uma nova sociedade. Estudos. Avançados, São Paulo, v. 24, n. 68, p. 9-13, 2010 . Disponível em:<<http://www.scielo.br/scielo.php?script=sci_arttext\&pid=S010340142010000100003\&lng=en\&nrm=iso>. Acesso em: 05 set. 2019. http://dx.doi.org/10.1590/S010340142010000100003.

ROGGERO, Marilia Araujo; ZIGLIO, Luciana. et.al. Vulnerabilidade socioambiental, análise de situação de saúde e indicadores: implicações na qualidade de vida no município de São Paulo, Confins, [online], 36 | 2018 Disponível em:<DOI : 10.4000/confins.13774>. Acesso em: 05. de set. de 2019.

SEVERINO, Joaquim Antonio. Metodologia do Trabalho Científico. São Paulo: Cortez, ed.22, 2002.

SIKKINK, Kathryn. et.al. New actor and new forces: transnational activist networks. International Politics: enduring concepts a contemporary issue. Londres: Pearson Longman, 2005.

SWYNGEDOUW, Erik. The Anthropo(Obs)cene. Antipode (Editors). Keywords in Radical Geography: Antipode at 50. The Authors/Antipode Foundation Ltd. Published by John Wiley \& Sons Ltd., 2019.

TAMIKO, Tsuru. Desemprego em massa, condições de vida e procura por trabalho: uma experiência japonesa. Trabalho Flexível, Empregos Precários. GUIMARÃES, Nadya Araújo; HIRATA, Helena; SUGITA, Kurumi (orgs.) São Paulo: EDUSP, pp. 233-270,2009. 
TATIM, Denise., DIEHL, Astor. Pesquisa em Ciências sociais aplicadas: métodos e técnicas. São Paulo: Prentice Hall, 2004. 168p.

UMBERTO, Eco. Como se fazer uma tese. São Paulo: Perspectiva, 1985.

VEIGA, José Eli da . Sustentabilidade: a legitimação de um novo valor. São Paulo: SENAC, 2010.

VILLA, Rafael Duarte. Formas de influência das ONGs na política internacional contemporânea. Revista de sociologia e política, Curitiba, n. 012, jun. 1999. 09. out. 2018. Disponível em: <http://revistas.ufpr.br/rsp/ article/view/39261 >. Acesso em: 05 de set. de 2019.

VILLA, Rafael Duarte. A construção de um sistema internacional policêntrico: atores estatais e não-estatais societais no pós-guerra fria. Revista Cena Internacional, Brasília, n. 2, p 65-87, dez. 2001. 